\title{
Melania Chotyńska
}

http://orcid.org/0000-0001-8394-8363

Uniwersytet Jagielloński

m.chotynska@interia.pl

DOI: $10.35765 /$ pk.2020.2902.04

\section{Bogdan Jański i jego współcześni}

\section{STRESZCZENIE}

Artykuł poświęcony jest postaci Bogdana Jańskiego - emigracyjnego działacza doby romantyzmu. Punkt wyjścia stanowi przedstawienie biografii założyciela zmartwychwstańców. Skonfrontowane zostały ze sobą różne wersje jego życiorysu: od hagiograficznej, poprzez popularną, aż po ściśle naukową. Przypomniana i wyjaśniona zostaje kwestia relacji Jańskiego z Adamem Mickiewiczem (osobista przyjaźń, wzajemne wpływy światopoglądowe). Ważny element wywodu stanowi ukazanie powiązań „apostoła emigracji” z innymi autorytetami duchowymi tego okresu. Artykuł ma na celu przypomnienie skomplikowanych i interesujących dziejów Jańskiego oraz miejsca, jakie zajmuje on w historii Wielkiej Emigracji, a także wyjaśnienie pewnych kwestii spornych związanych z jego biografią (np. zakresu wpływu Jańskiego na twórczość poetycką Mickiewicza).

SŁOWA KLUCZE: Bogdan Jański, Wielka Emigracja, Adam Mickiewicz, duchowość

\section{AB S T RAC T}

Bogdan Jański and his Moderns

The article is dedicated to Bogdan Jański- a migrant social activist of Romanticism. Firstly, the biography of Jański is examined. A few versions of this biography are confronted: from hagiographic, through popular, to historical. Relations between Jański and Adam Mickiewicz are analyzed (their friendship and mutual philosophical influences). The key point of this article is the analysis of relations between "The Apostle of Polish Great Emigration" and other spiritual authorities of Polish Romanticism. The article is a recollection of complicated an interesting story of Jański's life and his role in the history of Polish Great Emigration. It also clarifies certain facts related to his biography, such as Jański’s influence on Mickiewicz's poetic works.

KEYWORD S: Bogdan Jański, Polish Great Emigration, Adam Mickiewicz, spirituality

Sugerowane cytowanie: Chotyńska, M. (2020). Bogdan Jański i jego wspólcześni. Perspektywy Kultury, 2(29), s. 25-41. DOI: 10.35765/pk.2020.2902.04. 


\section{Wprowadzenie}

Lata 1830-1863 to czas rozkwitu literatury i kultury polskiej, a także tworzenia filozofii narodowej, będącej wspólnym dziełem uczonych i poetów o różnych zapatrywaniach społecznych, politycznych oraz religijnych. $\mathrm{Z}$ powodu ogólnie znanych uwarunkowań historycznych najwybitniejsi twórcy tego okresu działali na emigracji. Wielu z nich jest bardzo popularnych, istnieje jednak także rzesza postaci niemal całkowicie zapomnianych, pomijanych w opracowaniach, podręcznikach i kompendiach. Ich nazwiska pozostają nieznane szerokiemu gronu odbiorców kultury, a często nawet naukowcom zajmującym się polskim romantyzmem. Niniejszy tekst dotyczy właśnie takiej postaci - interesującej, wielowymiarowej, odgrywającej istotną rolę w życiu polskich emigrantów, a zarazem nieobecnej w zbiorowej pamięci.

Bohater artykułu nie był pisarzem ani artystą, lecz cieszył się przyjaźnią najwybitniejszych twórców polskiego romantyzmu i wywarł pewien wpływ na kształt niektórych dzieł Mickiewicza. Nie był filozofem, ale miał własny, oryginalny światopogląd, inspirujący dla wielu spośród jego wspólczesnych. Trudno go wreszcie nazwać przywódcą czy reformatorem religijnym, gdyż w przeciwieństwie do Towiańskiego nie sprzeciwiał się dogmatom Kościoła katolickiego. Ponadto zgromadzenie zakonu zmartwychwstańców, którego był pomysłodawcą, ukonstytuowało się już po śmierci inicjatora. Współcześni nazywali go „apostołem emigracji” (Gawecki, 1972, s. 5) i wydaje się, że jest to najwłaściwsze określenie, w pełni oddające istotę działań i wpływu wywieranego przezeń na środowisko polskich wychodźców.

\section{Dzieciństwo i wczesna młodość}

Bogdan Jański urodził się 26 marca 1807 roku w Lisowie koło Grójca. Jego ojciec, Piotr, był uczestnikiem kampanii napoleońskiej. Podczas przedłużającej się nieobecności męża Agnieszka Jańska, zmuszona trudną sytuacją materialną, pozbyła się części rodzinnego majątku w Pękowie. Ta decyzja stała się przyczyną konfliktu między małżonkami oraz późniejszej separacji. Efektem ekonomicznym tego posunięcia było z kolei popadnięcie rodziny w ubóstwo, którego skutki Bogdan miał odczuwać przez całe późniejsze życie.

Jako sześciolatek syn państwa Jańskich rozpoczął naukę w szkole elementarnej w Pułtusku. Szybko zdobył uznanie nauczycieli jako wyjątkowo zdolny i pracowity uczeń, odznaczający się „świetną pamięcią i zdolnościami językowymi” (Urbański, 2006, s. 11). Dobre wyniki udało mu się uzyskiwać także na następnym etapie edukacji, podczas nauki w Wojewódzkiej 
Szkole Benedyktyńskiej w Pułtusku. W 1822 roku ukończył ją z wyróżnieniem, a dzięki doskonałym wynikom i opinii bez trudu zdobył posadę nauczyciela w tej placówce. Praca Jańskiego w benedyktyńskiej szkole nie trwała jednak długo. Idąc za przykładem kolegów, a zapewne także na skutek osobistych ambicji oraz młodzieńczych pragnień wyrwania się z dobrze sobie znanego, prowincjonalnego środowiska, Bogdan zdecydował się na studia w Warszawie. Oznaczało to początek nowego rozdziału w jego życiu.

Pomimo wcześniejszych marzeń o studiowaniu filozofii Jański wpisał się jednak na Wydział Prawa, a po roku - na Wydział Ekonomii. Sumienna nauka na dwóch kierunkach, połączona z pracą zarobkową, nie przeszkadzała młodzieńcowi w prowadzeniu rozrywkowego trybu życia. Zarazem początek studiów zbiega się u Jańskiego z poważnym kryzysem wiary, spowodowanym według jego biografa (Micewski, 1983) po części wpływem środowiska, po części lekturą pism materialistycznych filozofów. Jest to okres, który podsumuje potem w osobistych notatkach jako „czas nierządu i nieroztropności” (Jański, 2000, s. 84), w duchu ostrej samokrytyki, charakterystycznej dla całego Dziennika.

Jak zostało wspomniane, moralne dylematy nie miały negatywnego wpływu na wyniki studiów Jańskiego. Przyszły ekonomista nie opuszczał licznych wykładów prowadzonych przez tak cenionych ekspertów, jak profesor Fryderyk Skarbek. W 1828 roku napisał pracę zatytułowaną Rzut oka na Polske pod rządami jej wskrzesiciela Aleksandra ${ }^{1}$, za którą otrzymał nominację profesorską w otwieranej właśnie Politechnice Warszawskiej, a przede wszystkim stypendium przeznaczone na podróż do Anglii, Niemiec i Francji. Miała to być wyprawa naukowa, zaś jej główny cel określono jako przygotowanie do „zorganizowania katedry handlowej w pierwszej w Polsce tego typu uczelni” (Micewski, 1983, s. 81). Jański nie mógł nie skorzystać z tak wielkiej szansy naukowego rozwoju. Jego zagraniczny wyjazd poprzedziła jednak decyzja o ożenku, podjęta w nietypowych okolicznościach i wprowadzona w życie z zaskakującym pośpiechem. Warto rzucić światło na ten nie tylko interesujący, ale także brzemienny w skutki fakt z życia Jańskiego, pomijany zresztą przez niektórych biografów ${ }^{2}$, zapewne jako niewygodny i w jakiś sposób nieprzystający do „hagiograficznego" wizerunku naszego bohatera.

1 Tytuł pracy brzmi kontrowersyjnie w kontekście patriotyzmu Jańskiego. Warto jednak przypomnieć, że pozytywna ocena cara Aleksandra I i wiązanie z nim wielkich nadziei dotyczących przyszłości kraju nie były bynajmniej rzadkim zjawiskiem wśród polskich uczonych tego okresu. Warto przeczytać pod tym kątem chociażby teksty Skarbka lub Pisma estetyczne Kazimierza Brodzińskiego.

2 Np. Hieronim Kajsiewicz, jeden z pierwszych biografów, pomija ten fakt całkowitym milczeniem - jak zauważył Micewski (1983) - zaś współczesny badacz Stanisław Urbański zbywa go za pomocą zaledwie jednego, niejasnego zdania (Urbański, 2006). 
Przyszła żona Jańskiego była jego sąsiadką z czasów pobytu Jańskich w Pękowie. Bogdan poznał ją we wczesnym dzieciństwie, zaś po latach nieoczekiwanie spotkał w Warszawie. Wówczas zakochał się w dawnej koleżance i poprosił ją o rękę, jednak dziewczyna odrzuciła oświadczyny. Kontakt został zerwany, zaś kilka miesięcy później Zawadzką spotkała przygoda nasuwająca nieodparte skojarzenia z pewnym fragmentem Potopu Sienkiewicza. Wacław Łuszczewski, jeden ze znajomych Aleksandry, zawarł z nią fikcyjne małżeństwo. Stało się to „przy udziale jednego z kolegów, który udawał księdza” (Sosnowski, 2016, s. 193), zaś naiwna dziewczyna dała się nabrać na ów „dowcip”. Kiedy po jakimś czasie zaszła w ciążę, Łuszczewski wyrzucił ją z domu. Odrzucona przez rodziców, zhańbiona Aleksandra znalazła wybawcę w Jańskim. Student zgodził się wziąć z nią ślub, wcześniej lojalnie informując o swoich zamiarach naukowej wyprawy za granicę. $Z$ uwagi na ciążę Zawadzkiej, a także zbliżający się termin wyjazdu, małżeństwo zostało zawarte bardzo szybko - jak podaje Andrzej Sosnowski, zaraz po uzyskaniu obowiązkowej dyspensy od zapowiedzi (Sosnowski, 2016). Ślub miał miejsce 23 października 1828 roku w Przewodowie, zaś następnego dnia Jański odjechał do Paryża. Już nigdy więcej nie zobaczył swojej małżonki.

\section{Przebudzenie duchowe. Saintsimonizm}

Stolica Francji była za czasów Jańskiego miejscem kiełkowania nowych idei i doktryn filozoficznych, ekonomicznych oraz społecznych. Jedną z nich był saintsimonizm - nurt socjalizmu utopijnego. W odróżnieniu od większości dawnych i współczesnych odmian socjalizmu doktryna ta nie wykluczała własności prywatnej, a jedynie poddawała krytyce pasożytnictwo i niesprawiedliwość społeczną. Zwolennicy Saint-Simona uważali, że istniejący system wymaga radykalnych zmian. Twierdzili, że stopniowe reformy w dziedzinie ekonomii i większe zwrócenie uwagi na sprawiedliwość w gospodarce poprowadzą ludzkość ku szczęśliwszym czasom epoce zrównania wszystkich klas i stanów. Nowy świat „miał być ukonstytuowany na podstawie rozumu, a więc (...) racjonalny i konsekwentnie usprawiedliwiony" (Kieca i Kleska, 2015, s. 46), a co za tym idzie - odrzucający religię objawioną lub też uznający ją jedynie za etap przejściowy w drodze ku szczęśliwemu życiu doczesnemu, będącemu „nową formą życia wiecznego" (Kieca i Kleska, 2015, s. 46).

Fascynacja Jańskiego saintsimonizmem mogła wynikać z kilku przyczyn. Pierwszą z nich był wspomniany już kryzys religijny i idąca za nim potrzeba szukania nowej idei, nadającej życiu sens i kierunek. Drugą poglądy Jańskiego na ekonomię, które w dużej mierze pokrywały się 
z przekonaniami saintsimonistów. Możemy wysnuć taki wniosek z jego negatywnej oceny istniejącego porządku społecznego, wyrażonej podczas dyskusji z Johnem Stuartem Millem. W owej dyskusji Jański „wystąpił przeciw wolnej konkurencji (...) i wadliwemu podziałowi dóbr, opartemu na egoizmie rządzących bogaczy” (Micewski, 1983, s. 100). Poddał również krytyce najważniejszą doktrynę swojego rozmówcy, czyli liberalizm gospodarczy, a to ze względu na charakterystyczny dlań „rażący brak współczucia dla biednych, poczucia solidarności z całą rodziną ludzką” (Micewski, 1983, s. 100).

Zaangażowanie Jańskiego w saintsimonizm trwało krótko, choć było bardzo intensywne. Młodzieniec „służył ruchowi z bojowym zapałem i neoficką gorliwością" (Kardaś, 2016, s. 22), usiłując przekonać do nowej idei zarówno środowisko emigracyjne w Paryżu, jak i ludzi poznanych w Londynie, gdzie udał się w dalszą podróż naukową. Niewątpliwie ważnym efektem jego członkostwa w ruchu było rozpoczęcie prowadzenia dziennika w celu duchowej odnowy i dążenia do moralnej doskonałości. Ostatecznie Bogdan porzucił zgromadzenie, zniechęcony licznymi sporami i rozłamem wśród jego członków. Niewykluczone, że ważną przyczynę stanowiła także programowa niechęć członków sekty do wszelkich „patriotycznych i narodowych uprzedzeń” (Hoffmann-Piotrowska, 2016, s. 53). Ruch socjalistów utopijnych miał charakter ponadnarodowy, zaś postawa Jańskiego była daleka od kosmopolityzmu, szczególnie od czasu wybuchu powstania listopadowego. Jego zaangażowanie w działalność patriotyczną z pewnością nie mogło się spodobać współbraciom. Na skutek tych i innych przyczyn niegdyś gorliwy saintsimonista w końcu opuścił zgromadzenie.

\section{Przyjaźń z Mickiewiczem. Droga do nawrócenia}

Rok 1830 to znacząca data zarówno w historii Polski, jak i w biografii Jańskiego. Właśnie wtedy miały miejsce wydarzenia, które zadecydowały o kształcie jego dalszego życia. Pierwszym z nich było przystąpienie do saintsimonistów, drugim - wyjazd do Londynu, czyli kolejny etap naukowej wyprawy, zaś trzecim i najważniejszym - wybuch powstania listopadowego. Informacja o zrywie została przyjęta przez Jańskiego z dużym niepokojem. Złe przeczucia dotyczące pozostałej w kraju rodziny szybko zamieniły się w pewność, gdy do Bogdana dotarła wieść o śmierci ojca. Piotr Jański zginął jako ochotnik w obronie Warszawy, a ,jego ciało znaleziono po bitwie przebite bagnetami i kulami” (Iwicki, 1989, s. 37). Kolejną tragiczną wiadomością była informacja o upadku powstania i następujących po nim represjach. Szczególnie jedna z nich wywarła wpływ na 
osobiste życie młodego ekonomisty. Decyzją Iwana Paskiewicza, namiestnika Królestwa Polskiego, nastąpiła likwidacja polskiego szkolnictwa wyższego. Szanse Jańskiego na pracę w Politechnice Warszawskiej, dla której prowadził swoje obserwacje, spadły do zera wraz z zamknięciem uczelni. Tym samym kilkumiesięczna praca badawcza okazała się bezużyteczna.

Jednakże narodowa klęska połączona z osobistą tragedią nie doprowadziły Jańskiego do rozpaczy, lecz skłoniły do intensywnych działań na rzecz kraju. Jeszcze w trakcie powstania pełnił w Paryżu i Londynie funkcję korespondenta i agenta w stopniu kapitana, zleconą mu przez Rząd Narodowy. Od 1831 roku zaczął pisać artykuły krytykujące rząd francuski za bierność w obliczu upadku powstania, nie miały one jednak szans na opublikowanie. Od tego momentu rozpoczyna się jego intensywna działalność w środowisku emigracyjnym, poprzedzona podjęciem trudnej decyzji o dobrowolnym pozostaniu za granicą. Jański zrezygnował z powrotu do kraju w myśl zasady wyrażonej przez Mickiewicza w Księgach narodu polskiego i pielgrzymstwa polskiego:

Pielgrzym polski powiada: Kto idzie za Wolnością, niech opuści Ojczyznę i odważy życie swoje.

Bo kto siedzi w Ojczyźnie i cierpi niewolę, aby zachował życie, ten straci Ojczyznę i życie; a kto opuści Ojczyznę, aby bronił wolność z narażeniem życia swego, ten obroni Ojczyznę, i będzie żyć wiecznie (Mickiewicz, 2019) $)^{3}$.

Cytowany tekst był doskonale znany Jańskiemu jako wydawcy i tłumaczowi na język francuski Ksiag narodu polskiego i pielgrzymstwa polskiego. Decyzja o służbie krajowi za granicą została jednak podjęta jeszcze przed ukazaniem się dzieła Mickiewicza. Zdaniem wielokrotnie cytowanego w niniejszym artykule Bolesława Micewskiego (1983) Ksiegi nie wywarły istotnego wpływu na postawę ideową młodzieńca; to raczej Jański wpłynął na poglądy, a w konsekwencji na twórczość poety. Rozmowy z pełnym zapału patriotycznego emigrantem stały się dla Mickiewicza źródłem wielu cennych refleksji, zawartych w katechizmie polskiej emigracji. Aby móc odnieść się do tego poglądu, warto prześledzić zarówno okoliczności owych rozmów, jak i dzieje tej interesującej przyjaźni.

Pierwsza listowna wzmianka Mickiewicza o Jańskim pochodzi z 28 lipca 1831 roku. W liście do Aleksandra Chodźki poeta prosi przyjaciela, by odebrał od Elizabeth Marlay książkę o saintsimonizmie i zwrócił ją „szanownemu Jańskiemu”, od którego zapewne dziełko zostało pożyczone, zaś Mickiewicz nie mógł go zwrócić osobiście z powodu pospiesznego

3 Cytowany fragment stanowi oczywiście parafrazę cytatu z Pisma Świętego (Łk 9,24). 
wyjazdu (Hoffmann-Piotrowska, 2016). Można zatem uznać, że zawarcie znajomości nastąpiło latem 1831 roku lub nieco wcześniej. Jański znał jednak dzieła wybitnego poety jeszcze na długo przed pierwszym spotkaniem z autorem Dziadów, a nawet przetłumaczył na francuski Konrada Wallenroda. Wzmianka z listu Mickiewicza pozwala mniemać, że zawarcie znajomości miało związek z propagowaniem przez Jańskiego saintsimonizmu wśród polskich i zagranicznych intelektualistów - wskazuje na to tematyka pożyczonej książki. Jak wspomniano, poeta nie mógł jej zwrócić osobiście, gdyż właśnie w lipcu 1831 roku opuścił Paryż i wyjechał do Polski celem wzięcia udziału w powstaniu. Powtórne spotkanie nastąpiło z inicjatywy Jańskiego w sierpniu 1832 roku, czyli natychmiast po powrocie Mickiewicza do Francji. Właśnie wtedy musiały mieć miejsce owe inspirujące rozmowy, które mogły wywrzeć wpływ na ostateczny kształt i wymowę ideową Ksiag narodu polskiego i pielgrzymstwa polskiego. We wrześniu tego samego roku przyjaciele zamieszkali razem.

Czas wspólnego mieszkania był dla Mickiewicza i Jańskiego okresem niezwykle pracowitym. Pierwszego z nich pochłaniało tworzenie opus magnum, czyli Pana Tadeusza, przerywane niekiedy pracą nad „Giaurem - szelmą i nudnikiem” (list Mickiewicza do Garczyńskiego cytowany za: Land, 1930, s. 610). Drugi rozpoczął redagowanie „Pielgrzyma Polskiego" - czasopisma emigracyjnego, a także wspomniany już przekład Ksiag narodu polskiego i pielgrzymstwa polskiego. Tłumaczenie dzieła zajęło Jańskiemu kilka miesięcy. Ostatecznie książka ukazała się w języku francuskim jako Le Livre des pèlerins polonais, napisana (podobnie jak oryginał) poetycką prozą oraz opatrzona wstępem Charles'a de Montalemberta - jednego ze znanych francuskich sympatyków sprawy polskiej.

Dzieło, które przekładał Jański, jest jednym z najważniejszych utworów Mickiewicza oraz istotnym źródłem wiedzy na temat światopoglądu poety. Bolesław Józef Gawecki, autor pracy o polskich myślicielach romantycznych (1972), zalicza filozofię Mickiewicza do kręgu przekonań mistycznych, czyli tych, które zakładają ciągłą interwencję świata duchowego w rzeczywistość materialną. Wskazuje przy tym na trzy źródła, które ukształtowały system przekonań Mickiewicza, czyli na „prostą, serdeczną wiarę; nieszczęścia Polski i własne; pokorę, którą mozolnie wypracował w duchu" (Gawecki, 1972, s. 50). Dziadów III część to efekt splotu tych trzech elementów i zarazem klucz umożliwiający zrozumienie filozofii poety. Księgi narodu i pielgrzymstwa, dzieło nieco późniejsze, jest z kolei zbudowane na fundamencie wiary w zbawcze posłannictwo narodu polskiego i jego „misję odkupicielską” (Gawecki, 1972, s. 50). Cierpienie Polski, będące efektem zbrodni, może mieć głębszy sens i odegrać istotną rolę w duchowych dziejach świata.

Okres przyjaźni z Mickiewiczem zbiega się u Jańskiego z jego przemianą wewnętrzną i nawróceniem. Trudno stwierdzić, czy poeta odegrał 
w tym procesie istotną rolę. Innymi słowy, nie wiemy, jak duży wpływ na Jańskiego miały omówione wyżej poglądy Mickiewicza. Wiadomo jednak, że poeta, aczkolwiek niechcący, stał się pośrednią przyczyną wielkiego kryzysu religijnego Jańskiego, przeżytego już po pierwszym zwrocie ku katolicyzmowi. „Winowajcą” był właśnie Le Livre des pèlerins polonais. Przekład dzieła miał odegrać ważną rolę propagandową i zyskać sympatię opinii publicznej dla sprawy polskiej. Grono wybitnych duchownych francuskich, pozyskane przez Mickiewicza i Jańskiego, otrzymało ważkie zadanie zdobycia poparcia papieża. Misja ta zakończyła się jednak „zupełną klęską” (Micewski, 1983, s. 195). Papież Grzegorz XVI wydał pismo ostro ganiące Le Livre des pèlerins polonais i wstęp Montalemberta, a zatem pośrednio również twórcę przekładu i całą ideę, która przyświecała dziełu. Stanowisko głowy Kościoła katolickiego względem sprawy polskiej załamało Jańskiego i spowodowało nawrót wątpliwości, przezwyciężonych po dłuższym czasie i z niemałym trudem.

\section{Powrót do Kościoła. Działalność apostolska}

Katechizm Kościoła katolickiego wspomina o dwóch rodzajach nawrócenia. Pierwszy z nich dotyczy pogan, którzy nie znają Ewangelii, ale poznawszy ją, przyjmują chrzest i zyskują dar nowego życia. Drugie nawrócenie jest procesem ciągłym, polegającym na nieustannej walce z grzechem z pomocą łaski Jezusa Chrystusa (Stownik zagadnień...). Pisząc o nawróceniu Jańskiego, mam na myśli oba te rodzaje, przy czym każdy z nich jest trudny do ujęcia w konkretne stwierdzenia i ramy czasowe. Psychomachia z oczywistych względów nie jest i nigdy nie będzie wdzięcznym przedmiotem naukowej analizy. Można jedynie wskazać kilka dat, faktów i cytatów, dających (lub też nie) wyobrażenie o procesie duchowej przemiany Jańskiego. Zarazem jednak należy zdać sobie sprawę, że najistotniejsza część tego procesu wymyka się „szkiełku i oku” i pozostanie sekretem niezgłębionym.

Intelektualne przyjęcie przez Jańskiego prawd wiary nastąpiło z całą pewnością wcześniej niż powrót do życia sakramentalnego. Jeszcze jako gorliwy saintsimonista podziwiał Chrystusa jako „pierwszego, ważnego reformatora społecznego" (Hoffmann-Piotrowska, 2016, s. 54). Później, po wydarzeniach związanych z powstaniem, zaczął upatrywać przyczyny klęski w moralnym i duchowym upadku Polaków oraz brać pod uwagę katolicyzm jako możliwy środek zaradczy. Już na początku 1832 roku na kartach jego dziennika pojawia się pomysł utworzenia nowego zakonu, a wcześniej - partii katolickiej. Wszystkie te przemyślenia nie idą jeszcze w parze z powrotem do Kościoła. Konwersja nastąpiła na przełomie 
1834 i 1835 roku. Jański przystąpił wówczas do spowiedzi generalnej, która, rozłożona na pięć faz, trwała 48 dni i zakończyła się przyjęciem Eucharystii 11 stycznia 1835 roku. Ów dzień został określony przez niego jako „na zawsze uroczysty” (Jański, 2000, zapis z dn. 10.02.1834).

Jak wynika z podanych już informacji biograficznych, Jański był zdecydowanie człowiekiem czynu, pracowitym i pełnym chęci do działania. Będąc saintsimonistą, w sposób aktywny poszukiwał członków nowego ruchu. Podobnie wyglądał jego powrót do Kościoła katolickiego. Osobiste nawrócenie chciał połączyć z nawracaniem innych, czyli „tworzyć nowych ludzi, oczywiście stawszy się samemu nowym człowiekiem" (Jański, 1991, s. 39). Za najlepszy środek do osiagnnięcia tego celu uznał tworzenie nowych katolickich wspólnot emigracyjnych.

Pierwsza mała grupa o charakterze religijnym została założona przez Jańskiego w marcu 1833 roku i składała się z samego pomysłodawcy, Adama Mickiewicza oraz Ignacego Domeyki, spotykających się na Carrefour de l'Observatoire 36. Z czasem przekształciła się ona w Stowarzyszenie Braci Zjednoczonych, działające od 19 grudnia 1834 roku i mające na celu wzajemną poprawę religijną i moralną. Pod wodzą Jańskiego zebrało się pokaźne grono emigrantów katolików, a wśród nich Adam Mickiewicz, Antoni Gorecki, Cezary Plater, Stefan Witwicki... Udział w stowarzyszeniu polegał na wspólnym słuchaniu Mszy zakończonym dyskusją, odbywającą się w każdy piątek. Zasadniczym celem miało być prowadzenie przez członków prawdziwie chrześcijańskiego życia i pozytywne oddziaływanie poprzez przykład na całe środowisko emigracyjne, pogrążone w „potępieńczych swarach”, a nierzadko w rozpaczy - nie tylko z racji fatalnej sytuacji politycznej, ale również problemów dnia codziennego, np. kłopotów materialnych.

Stowarzyszenie Braci Zjednoczonych funkcjonowało zaledwie kilka miesięcy. Micewski (1983) podaje interesującą przyczynę jego rozpadu: kiedy na świat przyszło pierwsze dziecko Mickiewicza (żonatego od lipca 1834 roku), warunki nie pozwalały już na wspólne spotkania odbywające się dotąd w domu poety. Oczywiście, nie jest to jedyny powód, dla którego bractwo nie wytrzymało próby czasu. Przeszkodę stanowił także fakt, że członkowie zgromadzenia byli w znacznej części zapracowanymi ludźmi nauki i kultury, zaangażowanymi w działalność zarobkową (wielu z nich miało na utrzymaniu rodziny) i patriotyczną. Porażka nauczyła Jańskiego, że podobne stowarzyszenie powinno składać się przede wszystkim z ludzi młodych, nieobarczonych tak wieloma obowiązkami, a przy tym pełnych entuzjazmu i zapału do pracy.

Bractwo Służby Narodowej zostało zawiązane w lutym 1836 roku, kiedy to Hieronim Kajsiewicz, przyszły kontynuator dzieła Jańskiego i wybitny kaznodzieja, „najął domek na ustroniu, gdzie zamieszkał 
razem z Antonim Goreckim, Bohdanem Jańskim, [Piotrem] Semenenką, [Edwardem] Duńskim, [Józefem] Ziemieckim” (Hahn, 1911, s. 30). Grono składało się przeważnie z młodzieńców przygotowujących się do stanu kapłańskiego. Wyjątek od tej reguły stanowił oczywiście sam Jański, któremu zawarte przed laty małżeństwo uniemożliwiło realizację powołania. Choć to Kajsiewicz „najął domek” będący miejscem wspólnego życia członków bractwa, w istocie trudno go uznać za założyciela zgromadzenia. Bratem Starszym został główny pomysłodawca projektu, a lokum przy ulicy Notre Dame des Champs 11 przeszło do historii jako Domek Jańskiego (fr. Maissonette de Janski). Dawny pracownik naukowy, działacz niepodległościowy, zaangażowany socjalista i filantrop odnalazł nareszcie zadanie, któremu miał się całkowicie poświęcić. Rozpoczął kolejny etap życia jako apostoł Wielkiej Emigracji, dążący ze wszystkich sił do moralnej odnowy własnej, powierzonej mu młodzieży oraz wszystkich „Polaków w pielgrzymstwie".

\section{Bractwo Służby Bożej i jego członkowie}

Jański poznał Piotra Semenenkę około 1833 roku. Młody emigrant ukraińskiego pochodzenia został jednym z pierwszych członków nowego zgromadzenia. Wkrótce dołączył do niego przywoływany już Hieronim Kajsiewicz - poeta, uczestnik powstania listopadowego. Wstąpienie do Bractwa Służby Bożej poprzedziła spowiedź oraz wspólne uczestnictwo w rekolekcjach w Solesmes jesienią 1835 roku.

Najważniejsze cele, które wytyczyli sobie współtowarzysze Jańskiego, to wspólna praktyka życia chrześcijańskiego oraz działalność apostolska wśród członków polskiej emigracji. Dzieło nawracania innych musiało zostać poprzedzone pracą nad własnym charakterem oraz przystąpieniem do sakramentu pokuty i Eucharystii. Zgodnie ze wskazówkami Jańskiego, bracia zamierzali „nad każdym dniem serio pracować, żeby go przepędzić święcie” (Jański, 1991, s. 33). W związku z tym wiedli bardzo uporządkowany tryb życia, w wielu punktach przypominający klasztorny rygor.

Bractwo Służby Bożej zmagało się z wieloma problemami w pierwszym i kolejnych etapach jego powstawania. Niektóre z nich wynikały z wewnętrznych rozterek braci, np. Semenenko i Kajsiewicz przez dłuższy czas rozważali wstąpienie do zakonu benedyktynów. Skutkiem namów Jańskiego zdecydowali się jednak pozostać przy wspólnocie i podjąć studia teologiczne, by lepiej jej służyć oraz realizować powołanie. Wspólnota zmagała się też z brakiem środków materialnych. Adam Mickiewicz, który od początku wspierał bractwo swoim autorytetem, nie zawsze mógł służyć bezpośrednią pomocą w tej sferze, lecz uruchomił swoje liczne wpływy 
i znajomości. Dowodem tego jest list poety do księcia Adama Czartoryskiego, zawierający prośbę o pożyczkę znacznej sumy pieniędzy; prośba została spełniona, co umożliwiło Kajsiewiczowi i innym zakwaterowanie na Notre Dame des Champs 11. Jański jednak niechętnie przyjmował wsparcie od zamożnych sympatyków, chciał bowiem, by Bractwo Służby Bożej było całkowicie niezależne. Przewidywał, że arystokraci mogą mu proponować pomoc finansową w zamian za poparcie konkretnych projektów politycznych, takich jak intronizacja wspomnianego księcia Czartoryskiego na króla Polski. Przyszłość w pełni potwierdziła zasadność jego obaw.

Być może Jański miał opory przed przyjmowaniem wsparcia także dlatego, że bał się, iż emigracyjne stronnictwa demokratyczne oskarżą go o konszachty $z$ arystokracją. Jeśli tak było, to równie dobrze mógł przyjąć pomoc, bowiem próba uniknięcia krytyki okazała się daremna. „Skrajna lewica (...) franksistowsko-masońska” (Micewski, 1983, s. 90) nieustannie przepuszczała ataki na nowe zgromadzenie, sięgając po kpiny i oszczerstwa. Cytowany powyżej Micewski, pisząc o lewicy „franksistowskiej”, miał zapewne na myśli frankistów - członków żydowskiej sekty religijnej, założonej w 1755 roku przez Jakuba Franka. Ich niechęć do bractwa mogła wynikać z niezbyt przychylnego podejścia do katolicyzmu. Z kolei ataki loży masońskiej miały konkretniejsze źródło. Jański, działając wśród polskich emigrantów i nawracając ich na prawowierny katolicyzm, odbierał tej organizacji potencjalnych lub nawet faktycznych członków (przykład: sam Semenenko, który przed wstąpieniem do Bractwa Służby Bożej przez jakiś czas był masonem). Zarzuty padały również ze strony arystokratycznej prawicy, źle ustosunkowanej do Jańskiego z opisanych powyżej przyczyn politycznych. Ataki w prasie miały bardzo poważne konsekwencje, czego przykładem są aresztowania braci przez władze francuskie pod fałszywym zarzutem spiskowania i wzywania do rewolucji.

Wszystkie wymienione przeszkody i trudności nie osłabiły zapału ewangelizacyjnego Jańskiego, który opracował nowy projekt wysłania do Rzymu najzdolniejszych członków organizacji. Mieli oni tam studiować teologię oraz otworzyć drogę kolejnym polskim księżom, pragnącym zdobyć wykształcenie w Wiecznym Mieście. Semenenko i Kajsiewicz spełnili zadanie, choć trzeba zaznaczyć, że wyjechali do Rzymu bez koniecznego zabezpieczenia, również finansowego, co sprawiło, że na miejscu musieli się zmagać z wieloma trudnościami i zapewne niejednokrotnie myśleli o porzuceniu swojej misji.

Praca i wymienione troski związane $\mathrm{z}$ prowadzeniem kongregacji poważnie nadszarpnęły zdrowie Jańskiego. Namówiony przez lekarzy, zdecydował się na wyjazd do Włoch. Pobyt ów służył nie tylko poprawie samopoczucia, ale również spotkaniu ze współbraćmi - Semenenką 
i Kajsiewiczem. Wyprawa nie przyniosła jednak oczekiwanego uzdrowienia. Na skutek postępującej gruźlicy „w Rzymie, w godzinach popołudniowych 2 lipca 1840 roku, w dzień Nawiedzenia Matki Najświętszej, w otoczeniu swoich przyjaciół i zaopatrzony świętymi sakramentami, umiera Bogdan Jański w trzydziestym trzecim roku życia” (Urbański, 2006, s. 70).

\section{Zmartwychwstańcy na tle życia duchowego epoki}

Jański jest nazywany założycielem zmartwychwstańców z racji podwalin, jakie położył pod powstanie tego zakonu. Jednak w istocie Zgromadzenie Zmartwychwstania Pana Naszego Jezusa Chrystusa powstało już po jego śmierci. Nazwa pochodzi być może od napisu wyrytego na nagrobku Jańskiego - Hic resurrecturus quiescit (pol. „Tu spoczywa mający zmartwychwstać”), zaś jej pomysłodawcą był Kajsiewicz. Nowe stowarzyszenie, które potem przekształciło się w zakon, powstało w Wielkanoc 1842 roku. Właśnie wtedy dawni członkowie Bractwa Służby Narodowej „złożyli śluby w kaplicy św. Sebastyana w katakumbach” (Hahn, 1911, s. 30-31), by następnie rozpocząć działalność w Paryżu.

Niezmiernie trudnym i bezcelowym przedsięwzięciem byłoby opisanie działalności zmartwychwstańców w odniesieniu do wszystkich zakonów, sekt i zgromadzeń działających w tym samym czasie pośród Wielkiej Emigracji. Z podobnych względów nie zamierzam także opisywać związków między regułą nowego zakonu a filozofią epoki romantyzmu. Celem artykułu jest jedynie prezentacja kilku charyzmatycznych postaci, pozostających w interesujących relacjach z nowym zgromadzeniem.

Pierwszą z osób, o których warto wspomnieć, jest Marcelina Darowska. Założyła ona pierwszy polski zakon żeński o celach edukacyjnych, u podstaw reguły którego leżało przekonanie, że „wykształcone porządnie matki-obywatelki, zdolne do heroizmu i poświęcenia” (Hoffmann-Piotrowska, 2016, s. 65) będą współtworzyć przyszłość kraju. Jak widać, Darowskiej przyświecał nie tylko cel religijny, ale również patriotyczny. Taka motywacja upodabnia ją do postaci Jańskiego i skłania niektórych badaczy (Hoffmann-Piotrowska, 2016) do przypuszczeń, że Zgromadzenie Sióstr Niepokalanego Poczęcia NMP powstało z inspiracji jego dziełem. Powyższą tezę potwierdza zauważony przez Kardasia (2016) fakt, że pierwsi zmartwychwstańcy byli spowiednikami Darowskiej i pomagali czynnie przy tworzeniu tego i innych nowych zakonów. Na koniec warto wspomnieć, że założycielka Zgromadzenia Sióstr Niepokalanego Poczęcia NMP jest błogosławioną Kościoła katolickiego; możliwe, że to samo będzie można wkrótce powiedzieć o Jańskim, którego proces beatyfikacyjny trwa od 2006 roku. 
Postacią daleko bardziej kontrowersyjną, lecz również związaną ze zmartwychwstańcami w nader interesujący sposób, jest matka Makryna Mieczysławska. Mowa o białoruskiej zakonnicy, która pod koniec lat 40. XIX wieku stała się sławna wśród paryskich emigrantów. Ogromną popularność zawdzięczała rzekomym prześladowaniom ze strony rosyjskiej Cerkwi. Mieczysławska, ksieni klasztoru bazylianek w Mińsku, wraz z pozostałymi siostrami była namawiana do konwersji na prawosławie. Pomimo zewnętrznego przymusu nie zgodziła się na zmianę wyznania, przez długi czas znosząc upokorzenia i tortury mające skłonić ją do zmiany decyzji. Po upływie ośmiu lat matce Makrynie udało się zbiec z klasztoru. We wrześniu 1845 roku dotarła do Paryża, gdzie opowiedziała historię swego męczeństwa wybitnym przedstawicielom emigracji. Jednym z nich był Juliusz Słowacki, który napisał poemat o swoim spotkaniu z bohaterską zakonnicą. Jego reakcję na historię Makryny biograf opisuje następująco:

Prostacza natura tej męczennicy, która potęgę wiary, siłę zdumiewającą swego ubogiego $\mathrm{w}$ zasoby wiedzy ducha, łączyła $\mathrm{z}$ wyglądem, gestami i mową klucznicy wiejskiej (...), wstrząsnęła [Słowackim] silnie. Słuchając jej prostej opowieści o znoszonych przez lat tyle najwyszukańszych męczarniach, nie znajdując w niej ni śladu jakiejś pozy czy pretensyi do wielkości i świętości, uznawał się w głębi sumienia słabszym moralnie, upokorzonym tą prawdą ducha tak potężnego, a tak skromnego i naturalnego (Tretiak, 1911a, s. 395, 400).

Upokorzenie poety zapewne nie byłoby tak wielkie, gdyby Słowacki znał istotną wartość owej „prawdy ducha”. Opowieść Makryny Mieczysławskiej była bowiem całkowicie zmyślona. Kobieta opisywała fałszywe dzieje zgromadzenia, do którego tak naprawdę nigdy nie należała, zaś materiału do kłamstwa dostarczyły jej zasłyszane pogłoski o prześladowaniu unitów w zaborze rosyjskim. Mistyfikacja ta została odkryta niemal sto lat później przez ks. Jana Urbana (1923), który ujawnił rozliczne sprzeczności i oczywiste fałsze obecne w relacjach Makryny.

Ogniwem łączącym sprytną hochsztaplerkę ze zmartwychwstańcami jest postać Aleksandra Jełowickiego, wpływowego brata działającego w rzymskiej siedzibie zakonu. Cieszył się on zaufaniem Grzegorza XVI. Kiedy Mieczysławska dotarła do Rzymu, udało jej się zmanipulować również papieża, a ten zlecił Jełowickiemu spisanie świadectwa zakonnicy. W ten sposób zmartwychwstańcy mimowolnie przyczynili się do rozpowszechnienia mitu matki Makryny.

Wiadomo ogólnie, że Andrzej Towiański odegrał niebagatelną rolę w życiu Mickiewicza, Słowackiego i kilku innych twórców polskiego romantyzmu. Osoba wieszcza jest istotnym, choć nie jedynym łącznikiem między misją apostolską Jańskiego a Kołem Sprawy Bożej. Zdaniem 
Hoffmann-Piotrowskiej (2016), gdyby Bractwo Służby Narodowej działało dłużej, a jego założyciel nie zmarł przedwcześnie, Mickiewicz mógłby nigdy nie zainteresować się towianizmem. Odłóżmy jednak na bok historie alternatywne i przyjrzyjmy się faktom.

Nauka Towiańskiego głoszona przezeń w Kole Sprawy Bożej opierała się na kilku fundamentach. Podstawowym było przekonanie, że obok świata widzialnego (materialnego) istnieje rzeczywistość duchowa. Człowiek może wybierać między wpływem dobrych i złych duchów, lecz jedynym słusznym dążeniem jest doskonalenie się i zbliżanie do Boga. Istotnym celem powinno być wzbudzenie w sobie miłości do Stwórcy, a następnie tzw. „realizacja ducha w ciele” (Tretiak, 1911b, s. 466), czyli nadanie duchowego sensu wszystkim elementom ziemskiego bytowania. Do tego momentu towianizm wydaje się całkowicie zgodny z teologią katolicką. Różnice napotykamy w założeniach dotyczących życia pośmiertnego. Towiański (a za nim jego wyznawcy i entuzjaści, w tym Słowacki) wierzył w metempsychozę, czyli wędrówkę dusz. Zgodnie z tym przekonaniem dobrzy ludzie stają się po śmierci czystymi duchami, zaś źli wracają do formy cielesnej tak długo, dopóki nie osiągną odpowiedniego stopnia moralnej doskonałości. Oczywiście, taki pogląd na sprawę był i jest nie do pogodzenia z nauką Kościoła katolickiego czy szerzej - z chrześcijańskim poglądem na świat, ma natomiast swoje korzenie w manicheizmie i jest ważnym elementem buddyzmu tudzież hinduizmu.

Stanowisko przyjęte przez zmartwychwstańców wobec postaci i nauki Towiańskiego to złożona kwestia. Założyciel Koła Sprawy Bożej był bliskim przyjacielem księdza Edwarda Duńskiego, jednego ze współpracowników Jańskiego z czasów Bractwa Służby Narodowej, późniejszego zmartwychwstańca. Tenże Duński okazał się zaskakująco wyrozumiały względem herezji Towiańskiego i wyrażał podziw dla szlachetnej, pełnej miłości bliźniego postawy życiowej założyciela Koła Sprawy Bożej. Warto nadmienić, że znał tego charyzmatycznego człowieka osobiście. Inni wpływowi zmartwychwstańcy, a mianowicie Kajsiewicz i Semenenko, nigdy nie zetknęli się z Towiańskim „twarzą w twarz”, a dogmaty wyrażone w jego pismach odrzucili z całą stanowczością. Gwałtowne szerzenie się nowej nauki wywołało nawet tak duży niepokój Kajsiewicza, że opuścił on Rzym i powrócił do Paryża, by opanować sytuację. Dziwnym zbiegiem okoliczności dzień po jego przybyciu Towiański został aresztowany i wydalony z Francji.

\section{$* * *$}

Bogdan Jański to jedna z ciekawszych postaci doby romantyzmu, a zarazem człowiek, którego przekonania i podejście do życia można uznać za uniwersalne. Pokonawszy młodzieńcze kryzysy, podjął trud pracy nad 
sobą i ponownych „narodzin z Ducha” (J 3,6-8). Przygnębiony narodową klęską, znalazł w sobie siłę, by walczyć ze zniechęceniem i brakiem nadziei wśród polskich emigrantów. Obdarzony dużymi zdolnościami, umiał poświęcić je dla wspólnego użytku, działając na rzecz narodu i Kościoła.

Pośród wybitnych i wpływowych jednostek każdej epoki możemy odnaleźć również podobne Jańskiemu „szare eminencje” ducha, które żmudną i wytrwałą pracą torują drogę przyszłej odnowie społeczeństw. Warto je przywracać zbiorowej pamięci.

\section{Bibliografia}

Chlebowski, B., Chrzanowski, I., Galle, H., Korbut, G. i Krzemiński, S. (red.). (1911). Wiek XIX. Sto lat mysli polskiej. Życiorysy, streszczenia, wyjątki. Warszawa: G. Gebethner i Spółka, t. 6.

Dziwisz, S. (2016). Homilia. W: W. Mleczko (red.), Stuga Boży Bogdan Jański. Doświadczenie duchowe i projekt spoteczny. Sosnowiec: Wydawnictwo św. Jana Pawła II, 7-11.

Gawecki, B. (1972). Polscy mysticiele romantyczni. Warszawa: Instytut Wydawniczy Pax.

Hahn, W. (1911). Kajsiewicz Hieronim (1812-1873). W: B. Chlebowski, I. Chrzanowski, H. Galle, G. Korbut i S. Krzemiński (oprac.), Wiek XIX. Sto lat mysli polskiej. Życiorysy, streszczenia, wyjątki. Warszawa: G. Gebethner i Spółka, t. 6.

Hoffmann-Piotrowska, E. (2016). Adam Mickiewicz - Bogdan Jański. Koincydencje nie tylko duchowe. W: W. Mleczko (red.), Stuga Boży Bogdan Jański. Doświadczenie duchowe i projekt społeczny. Sosnowiec: Wydawnictwo św. Jana Pawła II, 51-67.

Iwicki, J. (oprac.). (1989). Bogdan Jański: z okazji 150 rocznicy jego śmierci, 2 lipca 1840-1990. Tłum. W. Śpiewak. Rzym: Międzynarodowa Komisja Studiów Zmartwychwstańczych.

Jański, B. (1991). Mądrośćstużby. Wrocław: Wydawnictwo Wrocławskiej Księgarni Archidiecezjalnej.

Jański, B. (2000). Dziennik. 1830-1839. Rzym. Pozyskano z: http://biblioteka.xcr.pl/wp-content/uploads/2018/12/Dziennik-Janskiego.pdf (dostęp: 12.05.2020).

Kardaś, A. (2016). Bogdan Jański (1807-1840). W: W. Mleczko (red.), Stuga Boży Bogdan Jański. Doświadczenie duchowe i projekt spoteczny. Sosnowiec: Wydawnictwo św. Jana Pawła II, 17-28.

Kieca, M. i Kleska, Ł. (2015). Socjalizm utopijny Henri'ego Saint-Simona, Roberta Owena i Charlesa Fouriera. Rzeszów: Wydawca Łukasz Kleska. 
Kraushar, A. (1898). Frank i frankiści polscy, 1726-1816. Monografia historyczna osnuta na źódtach archiwalnych i piśmiennych. Kraków: G. Gebethner i Spółka, Gebethner i Wolff, W.L. Anczyc i Spółka.

Land, S. (1930). Mickiewiczowski przekład „Giaura”. Pamiętnik Literacki, nr 1, 608-623.

Micewski, B. (1983). Bogdan Jański - zatożyciel zmartwychwstańców 18071840. Warszawa: Ośrodek Dokumentacji i Studiów Społecznych.

Micewski, B. (1989). Bogdan Jański i geneza zmartwychwstańców. Studia Theologica Varsaviensia, nr 2, 81-89.

Mickiewicz, A. (2019). Ksiegi narodu polskiego i pielgrzymstwa polskiego. Pozyskano z: http://wspolnotapolska.org.pl/kultura/literatura/mickiewicz/ ksiegi-narodu-polskiego-i-pielgrzymstwa-polskiego.pdf(dostęp: 12.05.2020).

Mleczko, W. (red.). (2016). Stuga Boży Bogdan Jański. Doświadczenie duchowe i projekt społeczny. Sosnowiec: Wydawnictwo św. Jana Pawła II.

Nelli, R. (1979). Życie codzienne katarów w Langwedocji $w$ XIII w. Tłum. M. Ochab, Warszawa: PIW.

Słowacki, J. (1911). Rozmowa z matką Makryną Mieczysławską. W: B. Chlebowski, I. Chrzanowski, H. Galle, G. Korbut i S. Krzemiński (oprac.), Wiek XIX. Sto lat mysli polskiej. Życiorysy, streszczenia, wyjątki. Warszawa: G. Gebethner i Spółka, t. 6.

Stownik zagadnień omawianych w „Katechizmie Kościoła katolickiego”. Pozyskano z: http://www.teologia.pl/m_k/kkkln04.htm (dostęp: 12.05.2020).

Sosnowski, A. (2016). Prawna możliwość stwierdzenia nieważności małżeństwa Bogdana Jańskiego z Aleksandrą Zawadzką. W: W. Mleczko (red.), Stuga Boży Bogdan Jański. Doświadczenie duchowe i projekt spoteczny. Sosnowiec: Wydawnictwo św. Jana Pawła II, 191-211.

Tretiak, J. (1911a). Słowacki Juliusz (1809-1849). W: B. Chlebowski, I. Chrzanowski, H. Galle, G. Korbut i S. Krzemiński (oprac.), Wiek XIX. Sto lat mysli polskiej. Życiorysy, streszczenia, wyjatki. Warszawa: G. Gebethner i Spółka, t. 6.

Tretiak, J. (1911b). Towiański Andrzej (1799-1878). W: B. Chlebowski, I. Chrzanowski, H. Galle, G. Korbut i S. Krzemiński (oprac.), Wiek XIX. Sto lat mysli polskiej. Życiorysy, streszczenia, wyjatki. Warszawa: G. Gebethner i Spółka, t. 6.

Urban, J. (1923). Makryna Mieczystawska w świetle prawdy. Kraków: Nakład Przeglądu Powszechnego.

Urbański, S. (2006). Bogdan Jański. Cztowiek, który przekroczyt swoja mtodość. Warszawa: Wydawnictwo Szkoły Wyższej im. B. Jańskiego.

Wójtowicz, K. (2019). Droga charyzmatyczna Bogdana Jańskiego. Pozyskano z: http://www.resurrectionist.eu/assets/Spirituality/ReadingRoom/InPolacco/Droga-charyzmatyczna-Janskiego-tekst.pdf (dostęp: 12.05.2020). 
Melania Chotyńska - magister polonistyki, doktorantka na Wydziale Polonistyki Uniwersytetu Jagiellońskiego. Pracę naukową poświęca romantycznej niemieckiej teorii epopei w polskiej recepcji literackiej i krytycznej. Obecnie pod opieką prof. dra hab. Bogusława Doparta przygotowuje rozprawę doktorską poświęconą temu tematowi. W zakres jej zainteresowań naukowych wchodzi również biografia Bogdana Jańskiego jako tłumacza i interpretatora dzieł Adama Mickiewicza. 
